\title{
A SOLID PHASE ASSAY WITH RADIOACTIVELY- LABELLED ANTIBODY FOR THE DETECTION OF BRUCELLA ABORTUS
}

\author{
D. V. Wilson, Margaret J. Thornley and R. R. A. CoOmbs \\ Immunology Division, Department of Pathology, University of Cambridge, \\ at Addenbrooke's Hospital, Hills Road, Cambridge CB2 $2 Q Q$
}

\section{Plate XVII}

THE work described here forms part of an investigation into methods of detecting bacterial antigens for diagnostic purposes.

Classically, the immunological methods used in diagnosis have involved antibody detection, and although highly specific, they suffer from the disadvantage that serum antibodies may not be detectable until about 10 days after the onset of infection; there are also many problems of interpretation due to the persistence of antibodies after infection is past. Similar but even more striking drawbacks are encountered in the use of tests for cellular immunological reactivity. Isolation and identification of the causative agents require several days or longer.

Methods based on the immunological identification of the microbial antigen have potential advantages in speed and specificity. In practice, the most widely-applied of such methods are the fluorescent antibody techniques used for the identification of bacteria or viruses in secretions, tissues or faeces.

Soluble bacterial products, particularly the polysaccharides of capsular antigens, have been detected by immunological methods in body fluids including urine (Dochez and Avery, 1917), cerebrospinal fluid (Rake, 1933; Alexander, 1937) and serum (Dennis and Saigh, 1945), while antigenic material from the organisms causing trichinosis (Zapart, 1961; Machnicka-Roguska, 1963) and schistosomiasis (Okabe and Tanaka, 1958) has been found in urine. In the earlier investigations, precipitin tests were used to detect antigen, but greater sensitivity and speed were provided by a haemagglutination inhibition test, applied to cerebrospinal fluid by Warburton, Keogh and Williams (1949) for the diagnosis of Haemophilus influenzae type $b$. Counter-immunoelectrophoresis was introduced for the diagnosis of fulminating meningococcaemia by Edwards (1971), and was used in the identification of meninococcal group-specific polysaccharide in the cerebrospinal fluid (Greenwood, Whittle and Dominic-Rajkovic, 1971; Whittle et al., 1975), and for the differentiation of the specific polysaccharides of the pneumococcus and meningococcus and Haemophilus influenzae in the cerebrospinal fluid of patients with meningitis (Coonrod and Rytel, 1972). This method has the advantages of simplicity and speed, the results being obtainable within $1 \mathrm{~h}$ of receipt of the specimen.

Radioimmunoassay is a method of great sensitivity that has been applied successfully in the screening of blood donors for Australia antigen (Ling and Overby, 1972; Alter et al., 1973; Prince et al., 1973). It may be used to detect antigen in a great variety of specimens, e.g., serum, saliva, urine, stools (Irwin et al., 1975).

Conventional radioimmunoassay procedures which employ radioactively-labelled antigen require prior knowledge of the chemical nature of the substance to be detected, and are most satisfactory for homogeneous substances of a single molecular species. However, many bacterial antigens are complex mixtures of substances with different chemical properties and it would be a formidable task to prepare from them radioactively-labelled material suitable

Received 29 Jan. 1976; revised version accepted 23 Nov. 1976.

J. MED. MICROBIOL.-VOL. 10 (1977) 
for use in a competition assay. Even if a successful method could be developed for labelling the products from one bacterium, it would not necessarily be applicable to another.

By means of labelled antibodies these difficulties are largely avoided. Detailed knowledge of the likely antigen is not essential provided that specific antisera can be raised to it or obtained from naturally infected hosts. Another advantage is that the radiochemical manipulations are carried out on easily purified and characterised immunoglobulins.

This paper describes a solid phase assay in which labelled antibody (Wide, 1971) for soluble antigens derived from Brucella abortus was used. It is envisaged that such a method could be applied with little modification to the detection of other microbial antigens.

Brucellosis is a disease in which improved methods of diagnosis would be of great value. The detection of bacterial antigens in blood samples would clearly be complicated by the presence of antibody in the blood, and the effects of this on the assay have been investigated, with a view to the eventual development of a diagnostic test in which inhibitory effects of antibody are avoided.

\section{MATERIALS AND METHODS}

Microcrystalline cellulose was a grade marketed for thin layer chromatography (E. Merck, Darmstadt). Chemicals were the purest available laboratory grade and solutions were prepared in de-ionised water with conductivity $0.3 \mu$ mhos $\mathrm{cm}^{-1}$; radioactive sodium iodide was purchased from the Radiochemical Centre, Amersham. The assays were carried out in plastic tubes (Luckham, LP3) and plastic tubes were also used for all procedures involving dilute solutions in order to minimise loss by adsorption on the container. LKBWallac automatic $\gamma$ counters were used for the counting of assay samples.

Standard procedures (Williams and Chase, 1971; Weir, 1973) were used for isoelectric focusing, immunoelectrophoresis and crossed immunoelectrophoresis. Guinea-pig complement was used in all complement fixation tests. Assessment of the ratio of radioactive label bound covalently to protein, to that unbound, was carried out by ascending chromatography on thick paper (Gelman strips) with $0.5 \%$ trichloracetic acid as developing solvent.

The main assay buffer consisted of $0.9 \%$ sodium chloride solution $(500 \mathrm{ml}), 0.1 \mathrm{M}$ sodium phosphate solution, $p \mathrm{H} 7.5(500 \mathrm{ml}), 10 \%$ sodium azide solution $(5 \mathrm{ml})$, Tween $20(5 \mathrm{ml})$ and bovine serum albumin $(2 \mathrm{~g})$.

\section{Brucella abortus whole culture extract (WE)}

This material was prepared by Dr J. Keppie. B. abortus (strain 544) was grown in a defined medium with added erythritol and the harvested organisms were extracted with sodium dodecylsulphate (Keppie, Witt and Smith, 1971 and 1972). The ethanol precipitated material corresponding to $1.5 \times 10^{11}$ organisms per $\mathrm{ml}$ was suspended in $\mathrm{M} / 200$ sodium phosphate-buffered saline (PBS) and stored at $-20^{\circ} \mathrm{C}$.

\section{Preparation of a soluble fraction (SWE) from whole culture extract}

WE extract $(10 \mathrm{ml})$ was cooled in ice and water during treatment in an MSE ultrasonic disintegrator for $3 \mathrm{~min}$. Insoluble material was removed by centrifuging at $20,000 \mathrm{~g}$ for 20 min. and the supernate, which had an $\mathrm{OD}_{280}$ of $6 \cdot 7$, was examined by isoelectric focusing, gel diffusion and crossed immunoelectrophoresis. Other samples were dialysed against water and then subjected to microanalysis.

\section{Rabbit antisera to brucella organisms and their soluble products}

WE antiserum. An emulsion of WE $(2 \mathrm{ml})$ and incomplete Freund's adjuvant was injected intramuscularly into rabbits at two separate sites. One week later each animal 
received $2 \mathrm{ml}$ of WE in saline intramuscularly at each of two sites. After 4 weeks the rabbits were bled, or alternatively given booster injections.

Live-" 554" antiserum. This was prepared for us by Dr J. Keppie. B. abortus (strain 544) was grown in a defined medium (Anderson and Smith, 1965); the organisms were washed and suspended in saline at a concentration of $5 \times 10^{7}$ per ml. Two doses of $1 \mathrm{ml}$ live organisms were given intravenously at an interval of 1 week. Four weeks later the rabbits were bled.

Sonicated-WE antiserum. An emulsion containing sonicated WE $(0.1 \mathrm{ml})$, PBS $(0.4 \mathrm{ml})$ and complete Freund's adjuvant $(0.5 \mathrm{ml})$ was injected intramuscularly into rabbits. After 34 days, $1 \mathrm{ml}$ of 1 in 5 dilution in saline of supernate from sonicated WE was injected into three sites, followed 20 days later by $0.5 \mathrm{ml}$ supernate and $2.0 \mathrm{ml}$ of deposit. The rabbits were bled after 10 days and 14 days.

\section{Immunoglobulin fractions}

IgG fractions of the various sera were obtained by ion-exchange chromatography on QAE-Sephadex A50 by means of a newly developed system of gradient elution (Ward and Wilson, unpublished). The fractions shown by immunoelectrophoresis to contain IgG only were pooled, concentrated and passed through a short column of Sephadex G25 to replace the separation buffers with PBS. The eluted product was adjusted to a protein concentration between 5 and $10 \mathrm{mg}$ per $\mathrm{ml}$ and stored frozen until needed.

IgM fractions were obtained from different aliquots of the same sera by gel filtration on Sephadex G200.

All Ig fractions were checked for the absence of other serum proteins by immunoelectrophoresis with a sheep anti-whole-rabbit serum for development.

\section{Synthesis of cellulose-antibody complexes for use as solid phase reagents}

The method of Wide (1969) was used. Cyanogen bromide-activated microcrystalline cellulose $(500 \mathrm{mg}), 0 \cdot 1 \mathrm{M}$ sodium bicarbonate $(2 \mathrm{ml})$ and a solution of the appropriate immunoglobulin fraction ( $5 \mathrm{mg}$ in $0.5 \mathrm{ml}$ of PBS) were mixed and rotated overnight.

After thorough washing the solid phase reagent was suspended in assay buffer $(10 \mathrm{ml})$ and stored at $4^{\circ} \mathrm{C}$. Microanalysis of typical preparations suggested a $\mathrm{C}: \mathrm{N}$ ratio of $41 \cdot 8: 1 \cdot 57$, corresponding to about $0.1 \mathrm{mg}$ protein per $\mathrm{mg}$ cellulose. These suspensions were found to be equally effective in the assay after storage for 12 months at $4^{\circ} \mathrm{C}$.

\section{Radio-labelling of immunoglobulin fractions}

Reagents were dissolved in $0.25 \mathrm{M}$ sodium phosphate buffer $p \mathrm{H} 7.4$ and cooled to $4^{\circ} \mathrm{C}$ before use.

IgG from rabbit anti-brucella serum $(10 \mu \mathrm{g}$ in $10 \mu \mathrm{l}$ of PBS) was placed as a single drop in the bottom of an LP3 tube and radioactive sodium iodide solution $\left(1.5-2 \mathrm{mCi}\right.$ of $\left.\mathrm{Na}^{125 I}\right)$ was added. The solutions were mixed by means of a small disposable-plastic stirring rod, and the $p \mathrm{H}$ was checked with narrow range indicator paper. If necessary it was adjusted by adding 1 or 2 drops of $0 \cdot 02 \mathrm{M}$-phosphate buffer $p \mathrm{H} 4.4$ to bring it within the range 7.0-7.5. The mixture was cooled to $0{ }^{\circ} \mathrm{C}$ and $0.2 \%$ chloramine $\mathrm{T}$ solution $(25 \mu \mathrm{l})$ was added. After $30 \mathrm{~s}$ $0.8 \%$ sodium metabisulphate solution $(25 \mu \mathrm{l})$ was added, followed after a further $30 \mathrm{~s}$ by $1 \mathrm{ml}$ of a solution containing human serum albumin $(5 \mathrm{mg})$ and potassium iodide $(5 \mathrm{mg})$. The tube contents were mixed and $5 \mu \mathrm{l}$ removed for determination of the percentage incorporation of label into protein. The remainder was placed on a column $(25 \mathrm{~cm} \times 1.5 \mathrm{~cm})$ of Sephadex G25 previously equilibrated by overnight contact with $10 \%$ normal rabbit serum in PBS, followed by elution with PBS containing $0.01 \%$ sodium azide. Fractions of $5-\mathrm{ml}$ volume were collected in plastic tubes. Each fraction was examined by paper strip chromatography and the total amount of radioactivity it contained was also determined by counting small aliquots. Fractions containing significant amounts of radioactivity, of which at least $97 \%$ was bound to protein, were pooled and stored in plastic tubes at $4^{\circ} \mathrm{C}$. In most experiments $60-70 \%$ of the $125 I$ offered was incorporated into protein, corresponding to a specific activity in the product of $>100 \mu \mathrm{Ci}$ per $\mu \mathrm{g}$. 


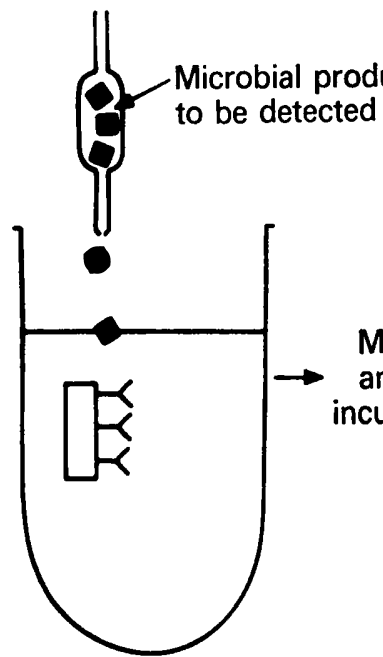

Sample added to suspension of cellulose-antibody

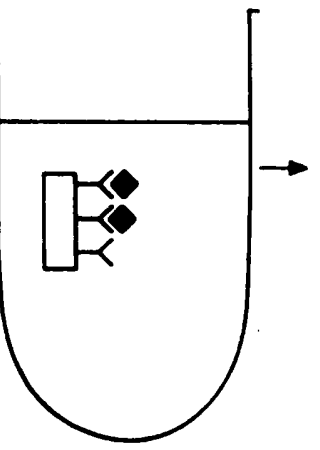

Binding occurs

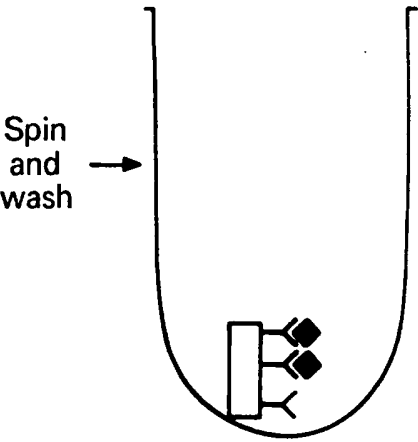

Microbial products in pellet

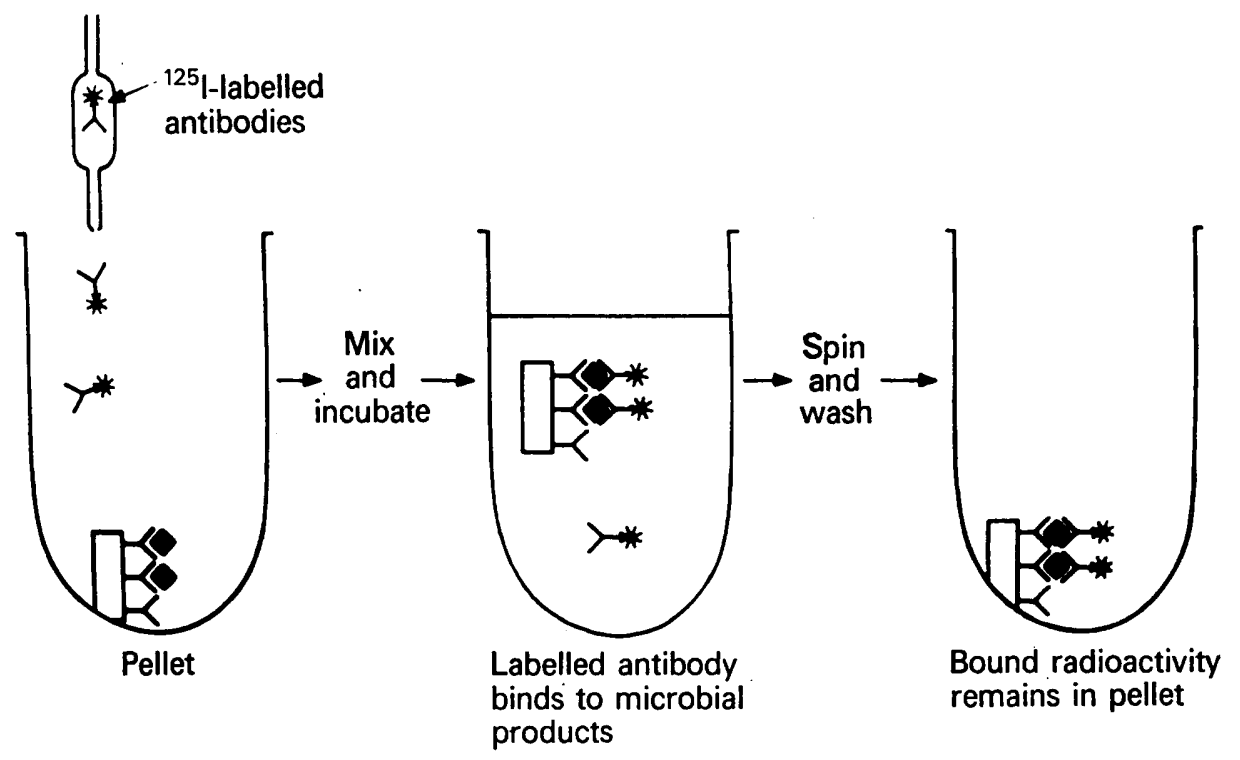

FIG. 1.-Principle of the solid phase, labelled antibody assay applied to microbial antigens. A sample of serum from the patient or a standard dilution of antigen is incubated with cellulose-antibody complex. Antigenic fragments derived from the infecting micro-organisms will be bound. Unbound material is removed by washing the pellet (stage I). Bound material is revealed by a second incubation with radioactively-labelled antibody capable of binding to other sites on the bound antigen. The amount of radioactivity in the pellet is related to the amount of microbial antigen in the sample tested (stage II). 
TABLE I

Chemical analysis of antigen from Brucella abortus

\begin{tabular}{|c|c|c|}
\hline \multirow{2}{*}{ Constituent } & \multicolumn{2}{|c|}{$\begin{array}{l}\text { Concentration (mg per ml) } \\
\text { of constituent in }\end{array}$} \\
\hline & WE & SWE* \\
\hline $\begin{array}{l}\text { Dry matter } \\
\text { Total protein } \\
N \text { (by Kjeldahl) } \\
\text { Amino sugars } \\
\text { Carbohydrate (as glucose) } \\
\text { Lipid }\end{array}$ & $\begin{array}{c}3 \cdot 2 \\
2 \cdot 2 \\
0 \cdot 38 \\
0 \cdot 06 \\
0 \cdot 26 \\
\text { Not measured }\end{array}$ & $\begin{array}{l}1 \cdot 4 \\
0 \cdot 93 \\
0 \cdot 18 \\
0 \cdot 037 \\
0 \cdot 23 \\
0 \cdot 31\end{array}$ \\
\hline
\end{tabular}

$\mathrm{WE}=$ Whole culture extract SWE $=$ soluble material obtained from WE after sonication.

* This fraction had a titre in complement fixation tests of 1280 .

Slow release of radioactive material that was not precipitable by $0.5 \%$ trichloracetic acid occurred during storage of labelled antibodies and it was necessary to repeat the gel filtration step at regular intervals. When this was done the label was usable for several weeks after the date of its preparation.

\section{Assay procedure}

The method is illustrated in fig. 1. A Cornwall pipette was used to dispense 1-ml portions from a vigorously stirred suspension of the cellulose-antibody complex (the stock solution diluted 1 in 400 with assay buffer) into LP3 tubes. Each tube received the equivalent of 0.7 $\mathrm{mg}$ (dry weight) of complex. Normal rabbit serum $(20 \mu \mathrm{l})$ was added and the tubes were incubated at room temperature and at the same time rotated end-over-end for at least $30 \mathrm{~min}$. The sample to be tested ( $100 \mu$ l of a solution previously diluted 1 in 5 with PBS), or $100 \mu$ l of a known solution of antigen in normal human serum diluted 1 in 5 with PBS was then added, and incubation with rotation was continued overnight $(17 \mathrm{~h})$.

The tubes were centrifuged for 3 min. at 4000 r.p.m. in an MSE Super Minor machine and the supernates were removed by means of a suction device so adjusted that $0.13 \mathrm{ml}$ of liquid remained in each tube. The pellets were washed three times with assay buffer $(1.5 \mathrm{ml}$ each wash) taking care that the cellulose-antibody pellet was resuspended each time. After removing the third wash supernate, labelled antibody ( $100 \mu \mathrm{l}$ containing about 1000 c.p.s.) was added together with more assay buffer $(400 \mu \mathrm{l})$ and normal rabbit serum $(20 \mu \mathrm{l})$ and the tubes were incubated with rotation for a further $3 \mathrm{~h}$. The cellulose-antibody complex was centrifuged down and washed three times with assay buffer as before and then any bound radioactivity was counted. Tubes containing cellulose-antibody complex but no antigen were always included as reference controls to which the counts in other tubes could be related.

The results are expressed as radioactivity bound (\%), given by

$$
\frac{S}{B} \times 100
$$

where $S$ is the radioactivity retained by the tube containing sample or standard and $B$ is the radioactivity retained by an identical tube containing no antigen. The test was invariably carried out on duplicate samples and the mean used in calculation.

\section{Results}

Characterisation of the antigenic material

Analytical data for WE and SWE are shown in table I. More prolonged ultrasonic treatment, or further treatment of the residue 


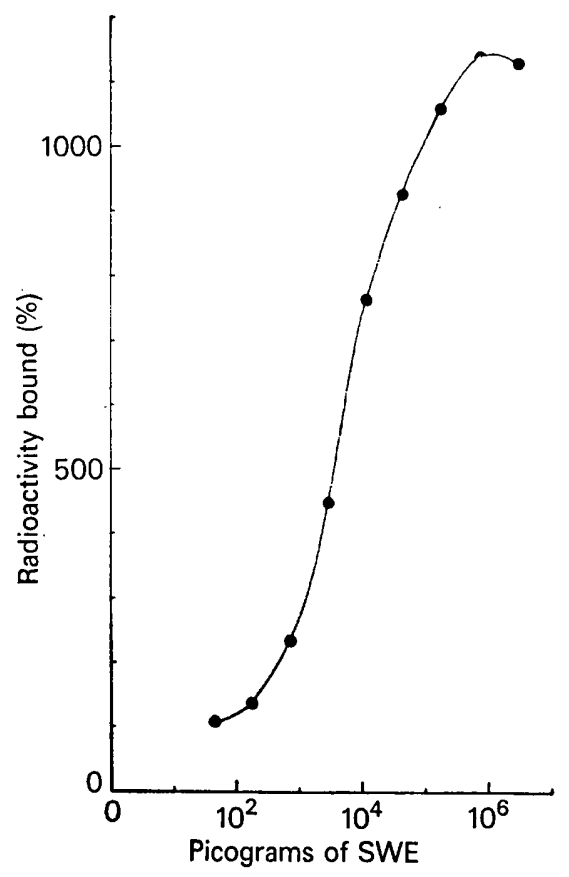

FIG. 3.

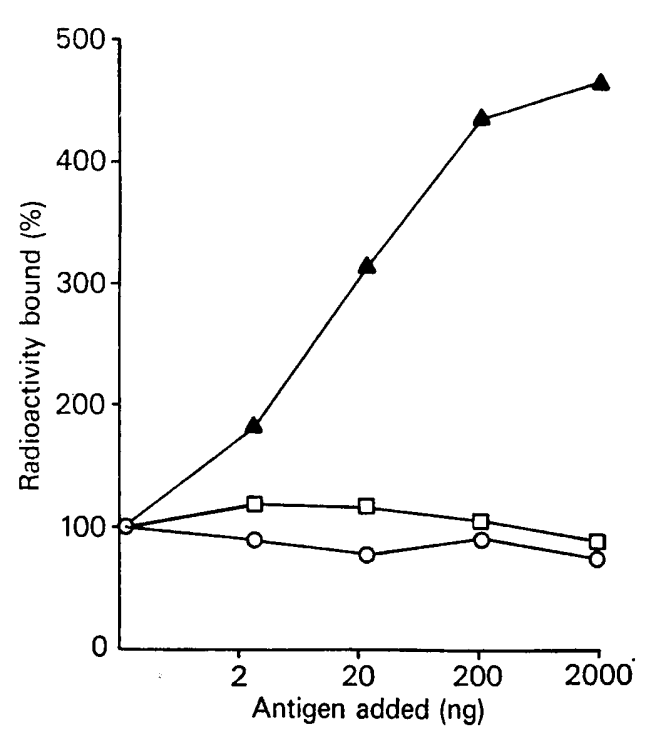

FIG. 4.

FIG. 3.-Standard curve obtained by assaying known amounts of SWE in the presence of normal human serum.

FIG. 4.-Requirement for specific reagents in the assay for brucella antigen. $\Delta$ Results obtained when both cellulose-antibody and complex labelled antibody were specific for brucella antigen (SWE). O A similar test where cellulose-antibody complex was prepared from anti-gonococcal serum. A similar test where the labelled antibody was prepared from anti-gonococcal IgG.

after removal of the supernate, gave only slightly increased yields of soluble material. WE was used without further treatment for raising antisera but in all other work, including derivation of standard curves, SWE was used.

\section{Electrophoretic investigation of SWE}

Samples were concentrated and subjected to isoelectric focusing on polyacrylamide gels (Salaman and Williamson, 1971). Fig. 2 shows a typical pattern of separated components made visible by staining with Coomasie Blue. No change in the number or intensity of bands was noticed when samples of supernate were re-run after storage at $-20^{\circ} \mathrm{C}$ for several months, but repeated freezing and thawing caused loss of the less intense bands and lowered intensity of the others. This deterioration was accompanied by apparent loss of material when samples were compared in the assay procedure itself against freshly solubilised material. Crossed immunoelectrophoresis of the soluble fraction and of material eluted from the isoelectric focusing plates indicated that five or six of the 14 bands stained with Coomasie Blue were capable of reacting with the various antisera against WE. Thus any or all of these antigens are 
likely to be detected in the assay as well as polysaccharides and lipopolysaccharides which would not be seen on the plates.

\section{Development of the assay}

Various incubation times, reagent volumes, buffer constituents, washing procedures and protein carriers were tried and as a result the standard conditions described under Materials and methods were adopted. A curve relating the amount of antigen in the sample to the increase in radioactivity retained in the pellet was obtained by analysing duplicate samples of pooled normal human serum to which known amounts of soluble extract had been added. Normal human serum has an effect on the test and for this reason all experiments were carried out in the presence of the same volume $(20 \mu \mathrm{l})$ of human serum, either the patient's sample or pooled serum to represent it.

\section{Derivation of a standard curve}

Fig. 3 shows the result of applying the assay to simulated samples with antigen concentrations varying from $100 \mathrm{pg}$ to $2.8 \mu \mathrm{g}$ per $20 \mu \mathrm{l}$ (dry weight). The increase in bound radioactivity is expressed as a percentage of that retained by identical tubes which had received no antigen. The maximum level of radioactivity bound is more than 16 times the minimum value obtained in the absence of antigen, and a near linear relationship exists over a substantial part of the range when a semi-logarithmic plot is adopted. Samples containing more than about $2.8 \mu \mathrm{g}$ show a slight inhibitory effect and lower counts than those for about 2.8 $\mu \mathrm{g}$ are recorded. An increase in the amount of celluloseantibody, because of higher background counts, also gives lower percentage increases in radioactivity for a given antigen concentration, amounting to about $40 \%$ decrease at the maximum of the curve when five times the standard amount of cellulose-antibody is present.

\section{Importance of antiserum fractionation}

An IgG fraction of the antiserum is essential for preparing a satisfactory cellulose-antibody reagent. Attempts to use an IgM fraction were unsuccessful; no significant increase in radioactivity was bound by tubes which had contained antigen. Whole serum could be used but background counts were much higher.

\section{Experiments to examine the antigenic specificity of the assay}

To establish the specificity of the assay, standard curves were derived under conditions where one or more of the components of the system had been replaced by a similar reagent prepared from antisera with different, unrelated, specificity. Fig. 4 summarises the results. It shows that replacement of labelled anti-brucella IgG with IgG from an anti-gonococcus serum radio-iodinated to a similar specific activity gave only background counts in all antigen-containing 
TABLE II

Application of the assay to normal human serum containing known amounts of brucella antigen

\begin{tabular}{c|cc}
\hline $\begin{array}{c}\text { Sample } \\
\text { number }\end{array}$ & $\begin{array}{c}\text { Antigen present } \\
\text { (ng) }\end{array}$ & $\begin{array}{c}\text { Antigen found } \\
\text { (ng) }\end{array}$ \\
\cline { 2 - 3 } 1 & $2 \cdot 80$ & $2 \cdot 82$ \\
2 & Nil & $<0 \cdot 2$ \\
3 & $28 \cdot 0$ & $25 \cdot 1$ \\
4 & $0 \cdot 28$ & $0 \cdot 83$ \\
5 & 280 & 288 \\
\hline
\end{tabular}

Antigen was diluted in normal human serum to the levels shown; duplicate samples $(20 \mu \mathrm{l})$ were then tested and the results calculated from a standard curve obtained at the same time.

TABLE III

Assay of human blood phagocytes containing intracellular brucella, added artificially

\begin{tabular}{|c|c|c|c|}
\hline $\begin{array}{l}\text { Sample } \\
\text { number }\end{array}$ & Dilution & $\begin{array}{l}\text { Brucella organisms } \\
\text { per ml }\end{array}$ & $\begin{array}{c}\text { Assay result } \\
\text { (pg per } 100 \mu \mathrm{l})\end{array}$ \\
\hline I & $\begin{array}{l}1 \text { in } 100 \\
1 \text { in } 1000\end{array}$ & $\begin{array}{l}1.5 \times 10^{7} \\
1.5 \times 10^{6}\end{array}$ & $\begin{array}{r}1000 \\
<100\end{array}$ \\
\hline II & $\begin{array}{l}1 \text { in } 100 \\
1 \text { in } 1000\end{array}$ & $\begin{array}{l}1.5 \times 10^{6} \\
1.5 \times 10^{5}\end{array}$ & $\begin{array}{l}<100 \\
<100\end{array}$ \\
\hline
\end{tabular}

The standard assay was applied to human white blood cells to which a known number of live brucella had been added. Results were calculated from a standard curve determined at the same time.

tubes and similar results were obtained with a cellulose-antibody reagent prepared from either anti-gonococcal IgG or normal rabbit IgG.

\section{Assay of test samples prepared in vitro}

The assay was used to examine a series of samples prepared by adding known amounts of antigen to normal human serum (table II) or live whole brucella organisms to human white blood cells (table III). Estimates of the amount of antigen obtained by reference to a standard curve made at the same time followed very closely the calculated values in the first case, but the sensitivity in the presence of whole cells seemed much lower. This may have been because less reacting antigen was present in whole bacteria, or because the bacteria were intracellular, or because of inhibition by constituents of human buffy-coat material.

\section{Effect of specific antibodies against $B$. abortus on the sensitivity of the assay}

To investigate the effect of the presence of antibodies in the sample, trials were made in which dilutions of rabbit anti-brucella serum were added to assay 


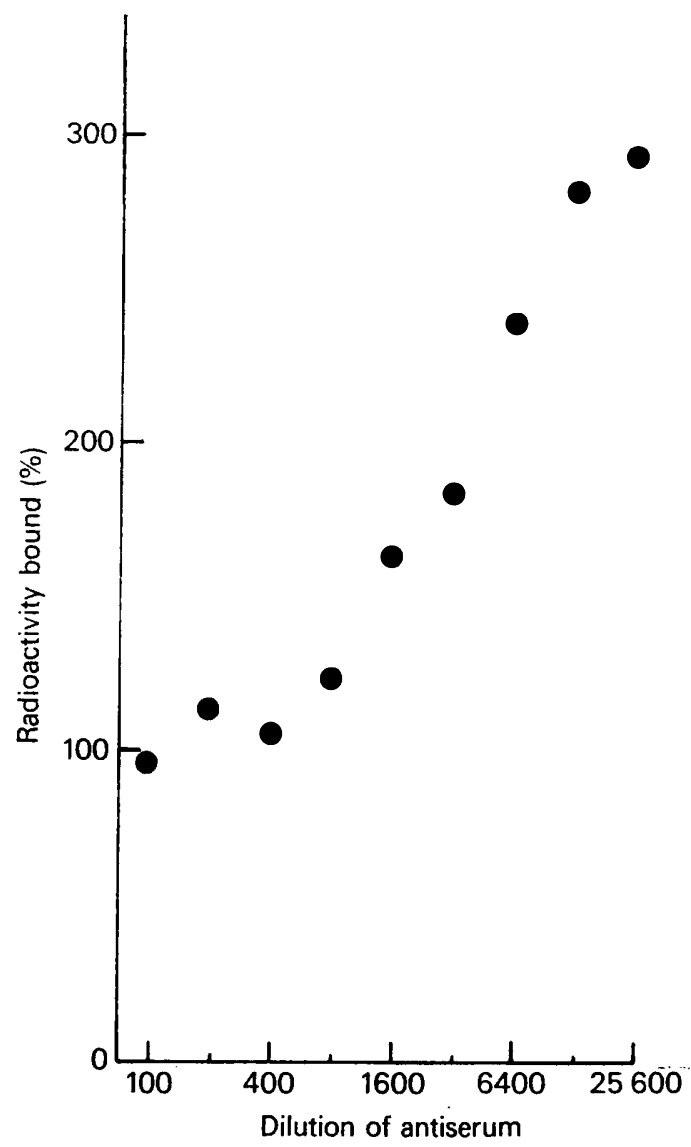

FIG. 5.-Effect of the addition of rabbit anti-brucella sera on the assay for brucella antigen.

tubes containing standard amounts of the brucella antigen. The inhibitory effect of the antiserum, even in small amounts, is shown in fig. 5.

Human serum samples from patients with brucellosis of the acute and chronic forms were obtained from Dr D. J. H. Payne, St Mary's Hospital, Portsmouth. Forty of these samples were tested without additions and gave negative results in the assay for brucella antigen. Twenty-eight were re-tested after a standard amount of SWE had been added to each. The inhibitory effects were striking, as shown by the results for 12 sera illustrated in fig. 6, and would probably be sufficient to conceal the presence of bacterial antigen had any been present in the patient's blood. However, in the early stages of the disease, before an antibody response has developed, antigen may well be detectable.

\section{Discussion}

The effectiveness of a solid phase assay of the type illustrated in fig. 1 is dependent on the quality of the reagents that are used. Provided that the antisera have adequate specificity and avidity, and the radioactive labelling or 


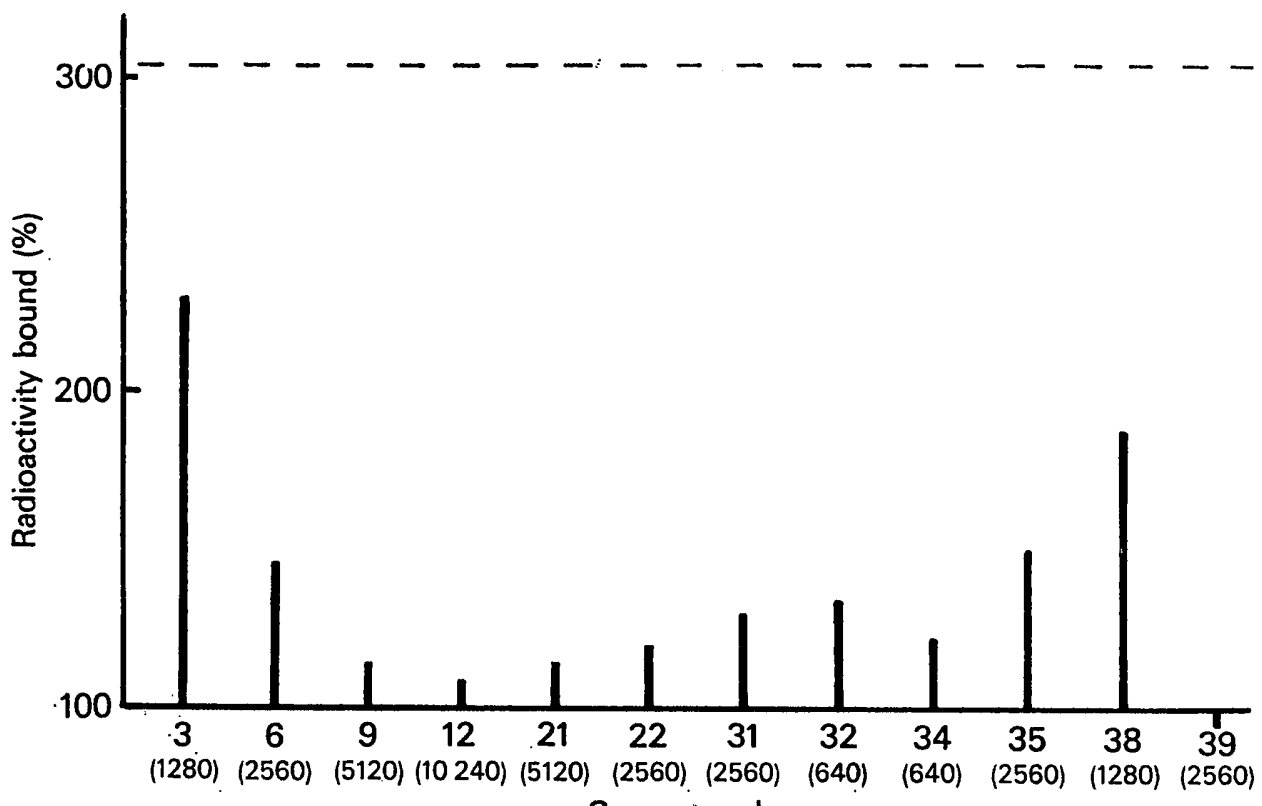

Serum number

Fic. 6. - Inhibitory effect of sera from brucellosis patients on the assay for brucella antigen. All tubes contained SWE at a dilution of 1 in 24000 . The radioactivity bound in the presence of normal human serum is indicated by the dotted line. Tubes that had received patients' serum bound the lower amounts of radioactivity indicated by the bars. The numerical values in parenthesis are titres obtained in a bacterial agglutination test with anti-human globulin.

chemical linking techniques do not materially reduce the binding properties, it should be possible to use the test for measurements in the picogram range.

In the present case the heterogeneity of the antigen poses certain problems of interpretation. Its chemical composition (table I) and behaviour on isoelectric focusing (fig. 2) show SWE to be a complex mixture of compounds and the crossed immunoelectrophoresis patterns suggest that antibodies to many of these different components are present in most antisera raised. Despite this heterogeneity in both antigen and antibody, the standard curves show a useful range over which unknowns may be measured. The present limit of detection is difficult to estimate because not all the components of SWE are likely to react. It must be less than $100 \mathrm{pg}$ per $20 \mu \mathrm{l}$ sample, and is possibly much less. It should be possible to increase the sensitivity in several ways: labelled antibody of higher specific activity would give some improvement and affinity-purification of the labelled antibody would lower the background level; antisera of greater affinity could result in increased radioactivity surviving the multiple washes and being retained in the final pellet.

The antigenic specificity of the assay appears already to be satisfactory. This is demonstrated by the low level of binding of unrelated radioactive antibody and the low level of binding when the solid phase reagent does not have the required specificity. Thus it appears that at least two sites on the antigen must be recognised for a positive response. Normal serum is slightly but definitely inhibitory in the assay, but in any routine development of the 
DETECTION OF B. ABORTUS BY LABELLED ANTIBODY

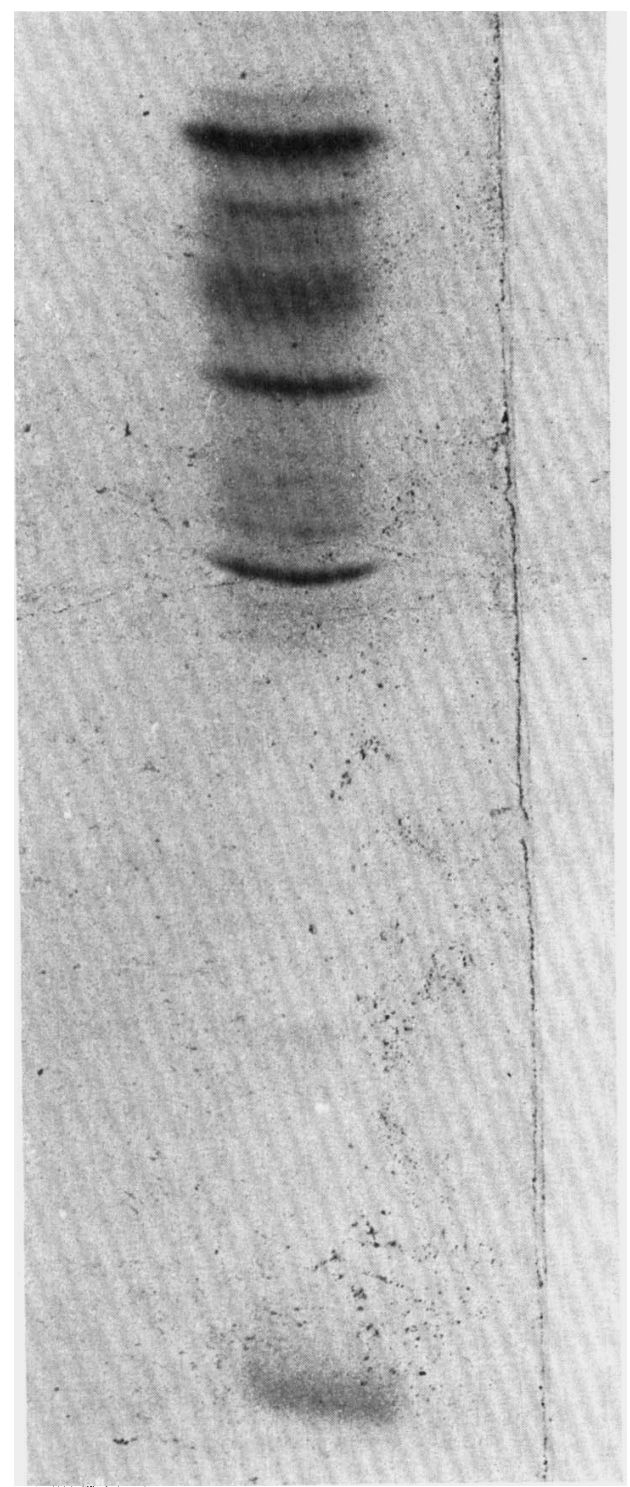

FIG. 2.-Thin-layer isoelectric-focusing separation of components of the soluble fraction (SWE) derived by ultrasonic treatment of brucella whole-culture extract (WE). 
test it will be possible to use samples of fixed volume and thereby standardise the extent of this non-specific inhibition.

More serious is the inhibition by natural antibody in the serum of brucellosis patients. The data in fig. 6 show the extent of inhibition to be generally related to antibody titre as measured in a standard bacterial agglutinationantiglobulin test, but two samples (nos. 32 and 34) with relatively low titres gave marked inhibition. For any practical application of the assay in diagnosis of brucellosis it will be necessary to overcome this inhibitory effect of natural antibody, either by testing serum taken at an early stage of the disease before the antibody response has developed, or when antigen is present in excess, or by finding antigenic material from $B$. abortus that does not under normal circumstances elicit antibodies in man.

An alternative approach would be to examine fragmented material from buffy coat which may contain brucella products.

\section{SUMMARY}

An assay for the detection of Brucella abortus is described. IgG from rabbit antisera against live brucellae or brucella extracts was chemically linked to cellulose to form a solid phase reagent capable of binding brucella antigens present in buffer solutions or serum. After washing away any unbound material the presence of bound antigen was revealed by incubation with radioactivelylabelled anti-brucella antibodies.

The assay was capable of detecting less than $100 \mathrm{pg}$ brucella antigen in a $20 \mu \mathrm{l}$ sample. Experiments in which IgG of non-related specificity was used in place of anti-brucella IgG showed that the test was specific. Normal human serum had only a slight inhibitory effect but anti-brucella antibodies were strongly inhibitory if present in the test sample. The extent of this effect and its relationship to antibody titre was investigated in 12 sera from brucellosis patients.

We thank Dr J. Keppie of the Microbiological Research Establishment for his most generous help and advice at all stages of the investigations and for gifts of brucella antigen and antisera; Dr D. J. H. Payne, Public Health Laboratory Service, St Mary's Hospital, Portsmouth, and Dr M. J. Corbel, Central Veterinary Laboratory, Weybridge, for gifts of sera and clinical samples; Dr J. Nagington, Public Health Laboratory Service, Addenbrooke's Hospital, Cambridge, and Dr J. Dawson, Veterinary Investigation Centre, Madingley Road, Cambridge, for useful discussions; and Mr Martin Ward, Miss Anna Mepham and Mrs Jane Harvey for skilled technical assistance.

The work was supported by grants from The Wellcome Trust and Roche Products Ltd, and had the support of the Procurement Executive, Ministry of Defence.

\section{REFERENCES}

AleXander, H. E. 1937. Prognostic value of the precipitin test in meningococcus meningitis. J. clin. Invest., 16, 207.

Alter, H. J., Holland, P. V., Purcell, R. H. and Gerin, J. L. 1973. The Ausria test: critical evaluation of sensitivity and specificity. Blood, $42,947$.

ANDERson, J. D. AND SMith, H. 1965. The metabolism of erythritol by Brucella abortus. J. gen. Microbiol., 38, 109. 
CoONROD, J. D. AND RYTel, M. W. 1972. Determination of aetiology of bacterial meningitis by counter-immunoelectrophoresis. Lancet, 1, 1154.

Dennis, E. W. AND SAIGH, A. S. 1945. Precipitable typhoid somatic antigen in serum of typhoid fever patients. Science, 102, 280.

Dochez, A. R. AND AVERY, O. T. 1917. The elaboration of specific soluble substance by pneumococcus during growth. J. exp. Med., 26, 477.

EDWARDS, E. A. 1971. Immunologic investigations of meningococcal disease. I. Groupspecific Neisseria meningitidis antigens present in the serum of patients with fulminant meningococcemia. J. Immun., 106, 314.

Greenwood, B. M., Whittle, H. C. and Dominic-Rajkovic, O. 1971. Counter-current immunoelectrophoresis in the diagnosis of meningococcal infections. Lancet, 2, 519.

Irwin, G. R., Allen, A. M., Bancroft, W. H., Karwacki, J. J., Brown, H. L., Pinkerton, R. H., Willhight, M. AND ToP, F. H. JR .1975. Hepatitis B antigen in saliva, urine, and stool. Infect. Immun., 11, 142.

KePpIE, J., WitT, K. AND Smith, H. 1971. A purified killed Brucella abortus vaccine. Br. J. exp. Path., 52, 365.

KePPIE, J., WITT, K. AND SMITH, H. 1972. The immunization of guinea-pigs and mice with a whole-culture extract of a smooth and a rough strain of Brucella abortus. Br. J. exp. Path., 53, 518.

LING, C. M. AND Overby, L. R. 1972. Prevalence of hepatitis B virus antigen as revealed by direct radioimmune assay with 125 I-antibody. J. Immun., 109, 834.

MACHNICKA-ROGUSKA, B. 1963. The occurrence of antigen in the blood and urine of rabbits in the course of experimental infection with Trichinella spiralis. Wiad. Parazyt., 9, 465.

OKABE, K. AND TANAKA, T. 1958. A new urine precipitin reaction for Schistosomiasis japonica, a preliminary report. Kurume med. J., 5, 45.

Prince, A. M., Brotman, B., Jass, D. ANd IKram, H. 1973. Specificity of the direct solidphase radioimmunoassay for detection of hepatitis-B antigen. Lancet, 1, 1346.

RAKE, G. 1933. Studies on meningococcus infection. V. The presence of meningococcus precipitinogens in the cerebrospinal fluid. J. exp. Med., 58, 375.

Salaman, M. R. AND Williamson, A. R. 1971. Isoelectric focussing of proteins in the native and denatured states. Biochem.J., 122, 93.

Warburton, M. F., KeOGh, E. V. AND Williams, S. W. 1949. A haemagglutination test for the diagnosis of influenzal meningitis. Med.J. Aust., 1, 135.

WeIR, D. M. 1973. Handbook of experimental immunology, 2nd ed., Oxford.

Whittle, H. C., Greenwood, B. M., Davidson, N. McD., Tomkins, A., Tugwell, P., Warrell, D. A., Zalin, A., Bryceson, A. D. M., Parry, E. H. O., Brueton, M., Duggan, M., Oomen, J. M. V. AND Rajkovic, A. D. 1975. Meningococcal antigen in diagnosis and treatment of group A meningococcal infections. Am.J. Med., 58, 823.

WIDE, L. 1969. Radioimmunoassays employing immunosorbents. Acta endocr., Copenhagen, Suppl. 142, 207.

WIDE, L. 1971. Solid phase antigen-antibody systems. In Radioimmunoassay methods, edited by K. E. Kirkham and W. M. Hunter, Edinburgh, p. 405.

Williams, C. A. AND ChASE, M. W. 1971. Methods in immunology and immunochemistry. Physical and chemical methods, New York and London, vol. 2.

ZAPART, W. 1961. Odczyn uroprecypitacji w rozpoznawaniu wlosnicy. Polski Tygod. lek., 16, 661 . 